\title{
INFLUENCE OF AMINO ACIDS AND ALCOHOLS ON CATALYTIC OXIDATION OF CYCLOHEXANE
}

\author{
Anatolij Ludyn ${ }^{1} \otimes$, Volodymyr Reutskyy ${ }^{1}$, Viktor Reutskyy $^{1}$, Yurij Hrynchuk $^{1}$
}

https://doi.org/10.23939/chcht15.03.352

\begin{abstract}
Conducted experiments and collected data show that use of catalytic systems that contain individual amino acids and industrial catalyst - solution of cobalt naphtenate with cyclohexanone - have certain influence on the process of liquid-phase homogeneous oxidation of cyclohexane. The results of spectral studies of binary catalytic systems based on $\mathrm{NC}$ using additives of different nature (alcohols and nitrogen-containing modifiers) allow us to propose structural formulas of catalytic complexes.
\end{abstract}

Keywords: oxidation, catalyst, cyclohexane, amino acid.

\section{Introduction}

All biochemical reactions that can be found in live organisms need presence of natural catalysts - ferments. In majority of cases ferments are relatively large protein formations, centre of which is chemically bonded molecule of non-protein nature or ion of metal. Ferments have critically large catalytic activity and selectivity but can be used only under mild conditions due to thermal instability of protein. On the other hand, main disadvantage of industrial processes of hydrocarbons oxidation is freeradical mechanism that needs hard conditions (temperature and pressure) and causes low selectivity during deeper oxidation. All the aforementioned causes high need in search of more efficient catalytic systems for industrial processes [1-2].

Main idea behind this research is a creation of new efficient and highly selective catalytic systems based on widely used industrial catalyst - cobalt naphtenate $(\mathrm{CN})-$ for the process of cyclohexane $(\mathrm{CH})$ oxidation. $\mathrm{CH}$ oxidation is industrially used process of synthetic fibres (nylon and capron) obtaining that have all features of freeradical processes -low conversion (near $4 \%$ ) and relatively low selectivity for aim-products (AP) under higher conversions. $\mathrm{AP}$ of $\mathrm{CH}$ oxidation process are cyclohexyl hydroperoxide (CHHP), cyclohexanole (COL) and cyclohexanone $(\mathrm{CON})$, by-products - adipic acid

\footnotetext{
${ }^{1}$ Lviv Polytechnic National University,

12, S. Bandery St., 79013 Lviv, Ukraine

anatolii.m.ludyn@lpnu.ua

(C) Ludyn A., Reutskyy Vol., Reutskyy Vic., Hrynchuk Yu., 2021
}

(AA) and dicyclohexyl adipinate (DCA). As additives for modification of industrial catalyst we tested amino acids. Amino acids were chosen in order to create catalytic systems that could have ferment-like properties (high efficiency and selectivity) but still would be thermally stable in industrial process. For research we choose three amino acids - glycine, L-arginine and DL - serine, to see if structure and size of catalytic additive would have influence on $\mathrm{CH}$ oxidation.

Experiments were made under conditions close to industrial ( $T=413 \mathrm{~K}, P=1.0 \mathrm{MPa}$ ) for two conversions $(X)$ - close to $4 \%$ (industrial conversion) and close to $7 \%$ (in order to observe tendencies of deeper oxidation). As catalytic systems the $\mathrm{CN}$ solutions with amino acids in $\mathrm{CON}$ were used. For comparison a solution of individual $\mathrm{CN}$ in $\mathrm{CON}$ (industrial catalyst) was used.

Chemical processes of oxidation play humongous role not only in industrial processes, but also in functioning of every living organism. All biochemical reactions present in any living organism are controlled and performed only in the presence of natural catalysts ferments. Ferments have critically large catalytic activity and selectivity but can be used only under mild conditions due to thermal instability of protein. In general, ferments are relatively large structures that consist of proteins and chemically bonded molecule of non-protein nature or ion of metal. Such structure allows to form large numbers of different combinations resulting in creation of very specific ferments for different processes from universal material. However, for a long time in industrial processes main criteria was not precision but efficiency of reaction equipment and rate of the process. Almost all industrial oxidation processes are radical processes. On one hand this fact solves rate problem - radical processes are fast and, in majority of cases, self-catalyzed after initiation stage, but on the other hand a relatively high rate leads to crucial fall of process selectivity and therefore - efficiency of reaction equipment. Traditionally this problem is solved by limitation of oxidation depth creating need of recycling of raw materials. Recycling, in its turn, leads to increase in production cost, number of additional processes and reagents and therefore amounts of the process sewage. All the aforementioned means that problem of search for new 
highly selective and efficient catalytic systems remains and will remain important [3, 4].

Despite high efficiency of heterogeneous catalytic systems in a number of processes, homogeneous catalytic processes remain more preferable for industry due to ease of installation in existing industrial schemes, ease of use, lower price, high adaptiveness to the changes in the process, and easier control of efficiency. For experiments process of cyclohexane $(\mathrm{CH})$ oxidation was chosen. $\mathrm{CH}$ oxidation is an industrially used process of obtainment of synthetic fibers - nylon and capron. Traditional and widely used catalyst for this process is naphtenate of cobalt (NC) [5-7].]

Previous research showed that additives of different nature have significant influence on catalytic performance of $\mathrm{NC}$ in $\mathrm{CH}$ oxidation process. Use of crown-ethers as catalytic additives to $\mathrm{NC}$ allows not only to increase conversion of $\mathrm{CH}$ but also to change ratio of main oxidation products - cyclohexanol/cyclohexanone. Such impact was explained by formation of catalytic active complexes [NC-crown-ether-substrate], in which cation of cobalt, $\mathrm{Co}^{\mathrm{n}+}$, played a role of complex creator and crown-ethers were used as ligands. Depending on different structure of crown-ethers ratio of aim products was shifted in both directions - creation of alcohol and creation of aldehyde [8].

Proposed structure of catalytic complexes remotely reminded structure of ferments. The main problem with recreation of ferment-like structure for oxidation catalyst is thermal instability of proteins and, therefore, proteins structures could not be used under industrial conditions due to thermal instability of proteins. However, proteins main building materials - amino acids- are far more thermally stable and, therefore, can be used under industrial conditions - high temperature and pressure [9-11].

Latest researches showed that indexes of oxidation processes are dependent on the presence of oxygen- and nitrogen-containing compounds, which in small quantities with catalyst can form active complexes or associates [1-3].

Amino acids contain two functional groups and, therefore, show properties of two classes of compounds carbonic acids and organic amines.

Regarding the place of amino group (related to carboxyl) the following amino acids are distinguished: $\alpha$ amino acids (amino groups are placed near first carbon atom, counting from carboxyl group), $\beta$-amino acid (near second carbon atom), $\gamma$-amino acid (near third carbon atom) and so on. All amino acids are highly reactive with ions of metals. Use of amino acids in combination with complex-creative ions of metal can allow to form in situ "nature-like" active and highly selective catalytic complex. All the aforementioned allows to expect different impact of amino acids on indexes of $\mathrm{CH}$ oxidation in the presence of organic salts of cobalt.

\section{Experimental}

Amino acids with different structure and properties were used. The research of influence of amino acids on the cyclohrxane oxidation was made for glycine, L-arginine, serine and R-serine (Fig. 1).<smiles>NCC(=O)O</smiles>

Glycine<smiles>N=C(N)NCCCC(N)C(=O)O</smiles>

Arginine<smiles>NCC(=O)O</smiles>

Serine

Fig. 1. Structural formulas of used amino acids

Glycine was chosen for experiments as the simplest amino acid that has no optical isomers. Due to its simplicity it is expected that it should be easier to enter this additive into catalytic system as ligand. It is also expected that relatively small sizes of created complex would allow it to be more active in oxidation process.

Arginine was selected because it is the "main building material" for majority of peptides and proteins. Especially it is essential for base proteins - histones and protamines - were its content could reach up to $85 \%$. Therefore, addition of arginine should allow to influence selectivity of the oxidation process.
Serine was chosen as one of the most important amino acids. Serine takes part in formation of almost all natural proteins. Especially significant role is played by serine in formation of proteolytic enzymes, where it forms active centres. Taking the above mentioned into account, use of serine as catalytic additive could have significant influence on selectivity of oxidation process and activity of catalytic system.

Structures of main components of catalytic system are presented in Fig. 2.

Ethanol $\left(-\mathrm{CH}_{3}-\mathrm{CH}_{2}-\mathrm{OH}\right)$ was used as a model alcohol additive to the catalytic system. 
<smiles>CCC1CCC(C)(C(=O)OC(=O)OC(=O)C2(C)CCC(CC)C2)C1</smiles>

Cobalt naphtenate<smiles>O=C1CCCCC1</smiles>

Cyclohexanone

Fig. 2. Structure of the components of the prepared catalytic systems

Dependences of liquid-phase $\mathrm{CH}$ oxidation in the presence of amino acids and alcohols were studied at the temperature of $413 \mathrm{~K}$ and the pressure of $1.0 \mathrm{MPa}$ in the reactor of bubbling type. The solution of $\mathrm{CN}$ in $\mathrm{CH}$ (base catalyst) and the $\mathrm{CN}$ solution in $\mathrm{CH}$ with addition of amino acids (researched catalysts) were used as the catalysts. The concentration of $\mathrm{CN}$ in reaction mixture was $10^{-4} \mathrm{~mol} / \mathrm{l}$. CN/amino acid ratio was $1: 1(\mathrm{w} / \mathrm{w})$. Technical oxygen was used as an oxidizer. Experimental data from $\mathrm{CH}$ oxidation in the presence of amino acids were compared with data obtained during $\mathrm{CH}$ oxidation with base catalyst.

\section{Results and Discussion}

\subsection{Catalytic $\mathrm{CH}$ Oxidation}

Experimental data obtained during research of liquid-phase homogeneous catalytic $\mathrm{CH}$ oxidation in the presence of amino acids is presented in Table 1.

Main indexes of selectivity for different $\mathrm{CH}$ conversions allow to analyze dependences of process dynamic at industrial conversion and during deeper oxidation stages.

Conversion $X=\sim 4 \%$, that is close to industrial index, and $X=\sim 7 \%$, that indicates deeper oxidation, allow to track tendencies of process development.
Research of CH oxidation in the presence of binary catalytic systems that contain glycine, arginine and serine, showed that addition of amino acids at time of analysis decreases conversion of raw material in comparison with indexes obtained in the presence of base catalyst with same duration of the process.

However, the presence of amino acids in the oxidation process leads to the increase of selectivity for aim products $\left(S_{\mathrm{AP}}\right)$ under industrial conversion $(X=\sim 4 \%)$ and under deeper oxidation stages $(X=\sim 7 \%)$ in comparison with base catalyst. As it is seen from Table 1 , the use of amino acids as catalytic additives shifts ratio of the aim products concentration to the creation of ketone. Data obtained at industrial conversion allows to expect effectiveness of researched catalytic systems under conditions close to industrial during pilot tests).

In all researched cases it is possible to observe growth of quantities of hydroperoxides at the starting stages of the oxidation with their further decrease on deeper oxidation stages in comparison with base catalyst. Such behavior can be explained by influence of amino acids functional groups at the radical-chain process. Analysis of sum selectivity for aim products at conversions 4 and $7 \%$ shows that presence of amino acids promotes processes of creation of secondary reaction products leading to increase of aim products yield (Fig. 3).

Table 1

Main indices of $\mathbf{C H}$ oxidation process for $\mathbf{C H}$ conversions

\begin{tabular}{|c|c|c|c|c|c|c|c|c|}
\hline Catalyst & $t, \min$ & $X, \%$ & $S_{\mathrm{CHHP}}, \%$ & $S_{\mathrm{AA}}, \%$ & $S_{\mathrm{DCA}}, \%$ & $S_{\mathrm{COL}}, \%$ & $S_{\mathrm{CON}}, \%$ & $S_{\mathrm{AP}}$ \\
\hline \multicolumn{9}{|c|}{$X=\sim 4 \%$} \\
\hline $\mathrm{CN}+\mathrm{CON}$ & 40 & 4.71 & 7.89 & 6.24 & 16.46 & 21.93 & 47.48 & 69.71 \\
\hline $\mathrm{CN}+$ Glycine & 60 & 4.65 & 7.43 & 9.04 & 0.75 & 23.74 & 59.04 & 82.78 \\
\hline $\mathrm{CN}+$ Arginine & 40 & 3.20 & 11.29 & 2.95 & 3.32 & 23.30 & 59.14 & 82.44 \\
\hline $\mathrm{CN}+$ Serine & 40 & 5.07 & 8.54 & 6.97 & 6.28 & 27.41 & 50.80 & 78.21 \\
\hline \multicolumn{9}{|c|}{$X=\sim 7 \%$} \\
\hline $\mathrm{CN}+\mathrm{CON}$ & 60 & 9.49 & 4.12 & 6.61 & 16.52 & 25.93 & 46.82 & 72.75 \\
\hline $\mathrm{CN}+$ Glycine & 80 & 5.40 & 7.16 & 8.33 & 0.00 & 33.67 & 50.84 & 84.51 \\
\hline $\mathrm{CN}+$ Arginine & 60 & 6.60 & 4.57 & 6.45 & 4.84 & 29.70 & 54.44 & 84.14 \\
\hline $\mathrm{CN}+$ Serine & 60 & 7.97 & 5.13 & 9.01 & 4.43 & 29.96 & 51.47 & 81.43 \\
\hline
\end{tabular}

Notes: CHHP - cyclohexyl hydroperoxide; AA - adipic acid; DCA - dycycloadipinate; COL - cyclohexanol, CON cyclohexanone, $\mathrm{AP}$ - aim products, $\mathrm{CN}+\mathrm{CON}$ - cobalt naphtenate (base catalyst) + cyclohexanone, $\mathrm{CN}+\mathrm{Glycine}-\mathrm{cobalt}$ naphtenate (base catalyst) + glycine, $\mathrm{CN}+$ Arginine - cobalt naphtenate (base catalyst) + arginine, $\mathrm{CN}+$ Serine - cobalt naphtenate $($ base catalyst) + serine, $X$ - conversion of cyclohexane, $S$ - selectivity for product. 
Use of amino acids under industrial conversion $X=\sim 4 \%$ and during deeper oxidation at $X=\sim 7 \%$ leads to notable decrease of the ethers formation process (main source of by-products - ethers). In particular, this dependence can be observed in the presence of glycine, and it is worth mentioning that it becomes stronger with increase of conversion of the raw material.

Another influence of the amino acids use in the process of $\mathrm{CH}$ oxidation is decrease of the dicarbonic acids (mainly adipic acid) formation (total selectivity for adipic acid formation equals to sum of selectivity for adipic acid and one third of selectivity for dicyclohexyl adipate). This decrease can be observed at starting stages of the oxidation process and at deeper stages of oxidation as well. This trend is especially observed in the presence of catalytic system [CH-CON-Arginine]. Such impact can be explained by formation of highly selective catalytic complex that increases the formation rate of aim-products $-\mathrm{CON}$ and $\mathrm{COL}-$ and blocks further oxidation into acids.

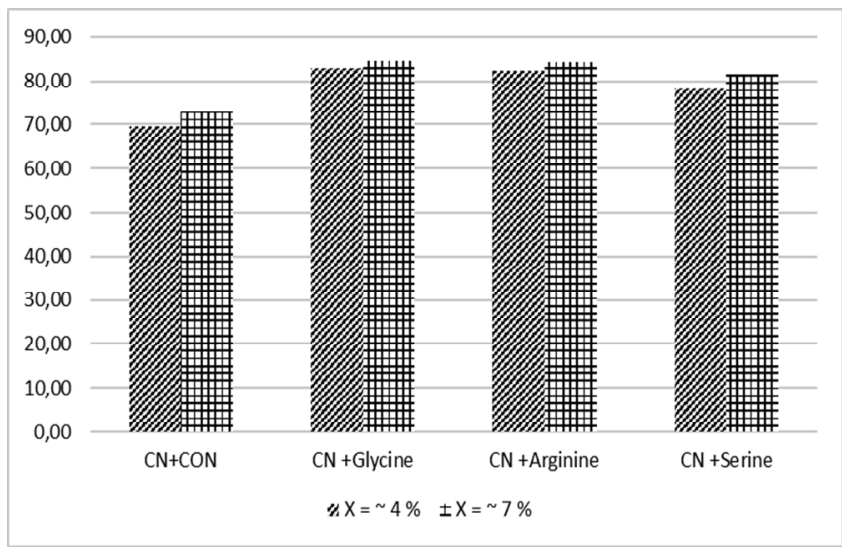

Fig. 3. Compared indexes of total selectivity for aim products of the $\mathrm{CH}$ oxidation under conversions $X=\sim 4 \%$ and $X=\sim 7 \%$ for catalytic systems with amino acids additives

The use of organic modifiers of different nature in the process of cyclohexane oxidation in the presence of cobalt naphthenate significantly affects both the composition of the products and the oxidation rate. This effect is associated with the participation of additives in the creation of intermediate complexes and associates with the catalyst and oxidation products. To verify these assumptions, spectral studies of solutions of complex catalytic systems were conducted.

After analyzing the results of the studies, the influence on the process of oxidation of cyclohexane of binary catalytic systems of different nature, we see that in the presence of such additives as ethanol (ET) and glycine (GL) to $\mathrm{NC}$, there are significant changes in the composition of the products and the process rate at different stages of oxidation (Table 2).

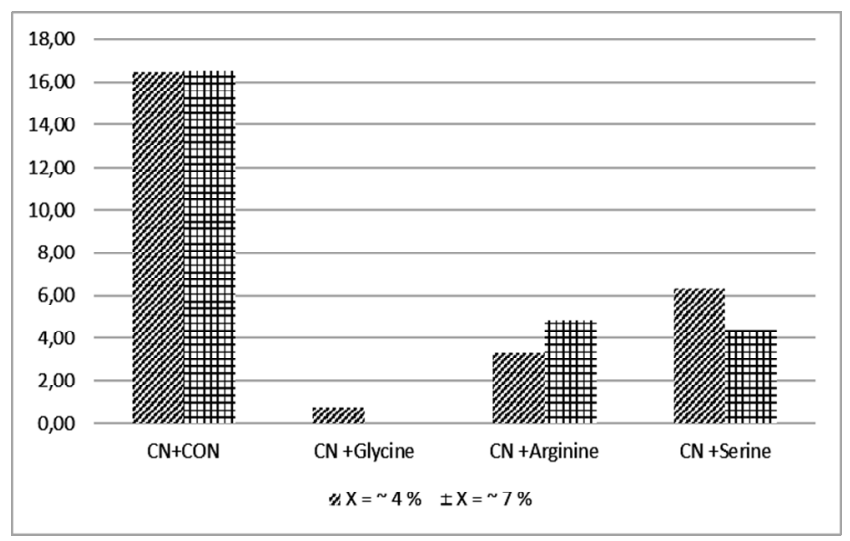

Fig. 4. Compared indexes of selectivity for dicyclohexyl adipate formation in the process of $\mathrm{CH}$ oxidation under conversions $X=\sim 4 \%$ and $X=\sim 7 \%$ for catalytic systems with amino acids additives

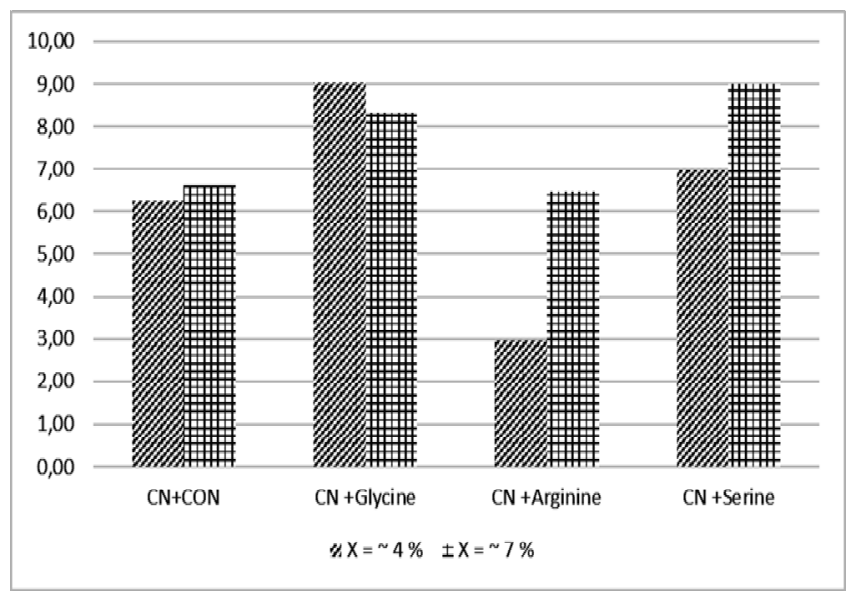

Fig. 5. Compared indexes of total selectivity for adipic acid formation in the process of $\mathrm{CH}$ oxidation under conversions $X=\sim 4 \%$ and $X=\sim 7 \%$ for catalytic systems with amino acids additives

Having analyzed the data obtained from use of two catalysts, we conclude that the nature of the action of these additives $(\mathrm{NC}+\mathrm{ET}$ та $\mathrm{NC}+\mathrm{GL})$ on the process selectivity is similar. The presence of additives leads to a slight change in the amount of HPCH in the oxidate, a significant decrease in the selectivity for acids and esters, as well as an increase in the concentration of COL and $\mathrm{CON}$, and together with shift in the ratio of $\mathrm{COL} / \mathrm{CON}$ towards the accumulation of alcohol. In this case, the effect on rate is multidirectional - ET accelerates the process, and GL slows it, compared to the NC. 
Table 2

Cyclohexane oxidation indices in the presence of organic modifiers of different nature $\left(X \approx 4 \%, T=413 \mathrm{~K}, P=1 \mathrm{MPa},[\mathrm{NC}]=5 \cdot 10^{-4} \mathrm{~mol} / \mathrm{l}\right)$

\begin{tabular}{|c|c|c|c|c|c|c|c|c|c|}
\hline$K, \%$ & $t, \min$. & $S_{\mathrm{HPCH}}, \%$ & $S_{\mathrm{AA}}, \%$ & $S_{\mathrm{DCA}}, \%$ & $S_{\mathrm{COL}}, \%$ & $S_{\mathrm{CON}}, \%$ & $W_{\text {mid }} \cdot 10^{3}, \mathrm{~mol} / 1 \cdot \mathrm{s}$ & {$[\mathrm{COL}] /[\mathrm{CON}]$} & $S_{\mathrm{AP}}, \%$ \\
\hline \multicolumn{10}{|c|}{$\mathrm{NC}$} \\
\hline 4.00 & 50 & 10.40 & 19.62 & 5.94 & 37.92 & 26.11 & 0.12 & 1.45 & 76.42 \\
\hline \multicolumn{10}{|c|}{$\mathrm{NC}-\mathrm{ET}$} \\
\hline 4.03 & 40 & 11.78 & 4.30 & 0.00 & 56.52 & 27.40 & 0.16 & 2.06 & 95.69 \\
\hline \multicolumn{10}{|c|}{$\mathrm{NC}+\mathrm{GL}$} \\
\hline 3.56 & 60 & 9.29 & 6.44 & 0.00 & 54.10 & 30.17 & 0.09 & 1.79 & 93.56 \\
\hline
\end{tabular}

Notes: $S_{\mathrm{HPCH}}$ is a selectivity for hydroperoxide of cyclohexane; $S_{\mathrm{AA}}$ is a selectivity for adipic acid; $W_{\text {mid }}$ is a middle speed of the reaction

Table 3

Results of IR spectrography of catalytic solutions

\begin{tabular}{|c|c|c|c|c|c|c|c|}
\hline \multicolumn{2}{|c|}{$\mathrm{NC}+\mathrm{CON}$} & \multicolumn{2}{|c|}{$\mathrm{NC}+\mathrm{CON}+\mathrm{GL}$} & \multicolumn{2}{|c|}{$\mathrm{NC}+\mathrm{CON}+\mathrm{GL}^{*}$} & \multicolumn{2}{|c|}{$\mathrm{NC}+\mathrm{CON}+\mathrm{ET}$} \\
\hline$v, \delta, \mathrm{cm}^{-1}$ & group & $v, \delta, \mathrm{cm}^{-1}$ & group & $v, \delta, \mathrm{cm}^{-1}$ & group & $v, \delta, \mathrm{cm}^{-1}$ & group \\
\hline- & - & 992 & $-\mathrm{C}-\mathrm{O}-$ & $\begin{array}{c}992 \\
\text { shifted }\end{array}$ & $-\mathrm{C}-\mathrm{O}-$ & - & - \\
\hline- & - & - & - & $\begin{array}{c}920 \\
\text { appeared }\end{array}$ & $\mathrm{C}-\mathrm{O}-\mathrm{C}$ & - & - \\
\hline & & 1040 & $\mathrm{C}-\mathrm{OH}$ & 1040 & $\begin{array}{c}-\mathrm{C}-\mathrm{OH} \\
\text { increasing }\end{array}$ & & \\
\hline 1260 large & $-\mathrm{CH}_{3}$ & 1260 small & $-\mathrm{CH}_{3}$ & 1260 & $-\mathrm{CH}_{3}$ & 1260 increasing & $-\mathrm{CH}_{3}$ \\
\hline 1296 small & $\mathrm{C}-\mathrm{H}$ & 1296 large & $\mathrm{C}-\mathrm{H}$ & 1296 & $\mathrm{C}-\mathrm{H}$ & 1296 increasing & $\mathrm{C}-\mathrm{H}$ \\
\hline- & - & 1664 & $-\mathrm{C}=\mathrm{C}-$ & 1664 & $-\mathrm{C}=\mathrm{C}-$ & - & - \\
\hline 1640 & $\mathrm{C}=\mathrm{O}$ & $\begin{array}{c}1640 \\
\text { increasing }\end{array}$ & $\mathrm{C}=\mathrm{O}$ & 1640 & $\mathrm{C}=\mathrm{O}$ & 1640 increasing & $\mathrm{C}=\mathrm{O}$ \\
\hline $3300-2800$ & $\mathrm{OH} \ldots \mathrm{H}$ & $3300-2800$ & OH...H & $\begin{array}{l}3300-2800 \\
\text { decreasing }\end{array}$ & OH...H & - & - \\
\hline $3700-3500$ & - & $3700-3500$ & $-\mathrm{OH}$ & $3700-3500$ & $-\mathrm{OH}$ & - & - \\
\hline- & - & - & - & - & - & $\begin{array}{c}3700-3100 \\
\text { appeared (wide) }\end{array}$ & $\begin{array}{l}-\mathrm{OH}, \\
\mathrm{OH} \ldots \mathrm{H}\end{array}$ \\
\hline
\end{tabular}

Note: * a solution $\mathrm{NC}+\mathrm{CON}+\mathrm{GL}$ after heating for 10 min at $413 \mathrm{~K}$

The nature of the studied catalytic systems, which include alcohols of different nature and amino acids, is associated with the formation of complex compounds or ionic associates involving functional groups of additives with a metal-containing catalyst molecule. Spectral analyzes of solutions of catalytic systems were carried out to support this theory.

IR spectroscopy of the analyzed colloidal solutions of the catalytic systems was performed using a Specord M-80 spectrometer in $0.2 \mathrm{~mm}$ cells. The analysis of the obtained spectra was performed on the basis of the tables of characteristic absorption frequencies given in $[9,10]$.

$\mathrm{CON}$ was used as solvent, which in the conditions of the oxidation process is present in the reaction medium, and cobalt naphthenate under normal conditions is better soluble in it than in $\mathrm{CH}$ and COL. The concentration of
MVV salts in the test solutions was $5.0 \cdot 10^{-5} \mathrm{~mol} / \mathrm{l}$. The total concentration of the catalytic solution was $5 \mathrm{wt} \%$. Among the tested organic additives GL and ET were selected. The ratio between the components of the catalytic system was [NK:additive] $=1: 1(\mathrm{w} / \mathrm{w})$.

Comparing the IR visible spectra of the prepared catalytic solutions with the spectrum of the NK solution, we see a number of significant changes in the absorption bands at certain frequencies (Table 3 ).

The sample $(\mathrm{CON}+\mathrm{NC}+\mathrm{ET})$ does not absorb at wavelengths of $3300-2800 \mathrm{~cm}^{-1}$ but there is a broad peak in the range of $3700-3100 \mathrm{~cm}^{-1}$, and for the samples $(\mathrm{CON}+\mathrm{NC})$ and $(\mathrm{CON}+\mathrm{NC}+\mathrm{GL})$ there are two broad peaks within $3700-3500$ and $3300-2800 \mathrm{~cm}^{-1}$, that correspond to the $\mathrm{OH}$ groups in complexes with hydrogen bonds. 
For the sample $(\mathrm{CON}+\mathrm{NC}+\mathrm{GL})$, the peak at $1296 \mathrm{~cm}^{-1}$ is large, and the peak at $1260 \mathrm{~cm}^{-1}$ is small, while for the sample $(\mathrm{CON}+\mathrm{NC})$ vice versa (at $1296 \mathrm{~cm}^{-1}$ is a small peak and at $1260 \mathrm{~cm}^{-1}$ is a large one). The peak at $1296 \mathrm{~cm}^{-1}$ corresponds to the absorption of $\mathrm{C}-\mathrm{H}$ in alkanes and increases due to $\mathrm{CH}_{2}$ in the amino acid. The absorption intensity at $1640 \mathrm{~cm}^{-1}$ increased for the sample $(\mathrm{CON}+\mathrm{NC}+\mathrm{GL})$ compared to $(\mathrm{CON}+\mathrm{NC})$, which corresponds to $\mathrm{C}=\mathrm{O}$ in amino acid. For $(\mathrm{CON}+\mathrm{NC}+\mathrm{GL})$ the peak at $1664 \mathrm{~cm}^{-1}$ corresponding to $-\mathrm{C}=\mathrm{C}$-increased as a result of the possible interaction.

After the addition of ethanol, the peak in the IR spectra of $(\mathrm{CON}+\mathrm{NC}+\mathrm{ET})$ became sharp, more pronounced, which can be explained by the formation of more polar molecules - micelles.

After heating (sample $\mathrm{CON}+\mathrm{NC}+\mathrm{GL}$ ), a peak appeared at $920 \mathrm{~cm}^{-1}$, which corresponds to $\mathrm{C}-\mathrm{O}-\mathrm{C}$ bonds, and the interaction between the components of the catalytic solution probably occurred. The absorption maximum at $992 \mathrm{~cm}^{-1}$ shifted toward longer wavelengths, which corresponds to $\mathrm{C}-\mathrm{O}$.

Most of the hydrogen bonds were destroyed after heating because the $3400-3000 \mathrm{~cm}^{-1}$ range was smaller than those of $(\mathrm{CON}+\mathrm{NC})$ and $(\mathrm{CON}+\mathrm{NC}+\mathrm{GL})$ samples

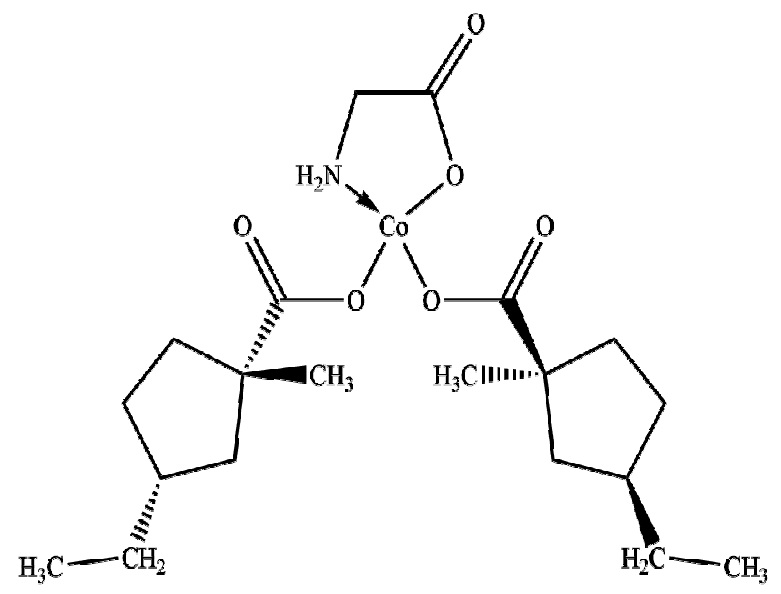

without heating. After heating, the intensity of all the peaks increased, especially the absorption peak at $1040 \mathrm{~cm}^{-1}$, corresponding to the $-\mathrm{C}-\mathrm{OH}$ group of atoms, that is, interaction in this group increased.

Therefore, summarizing the results of IR spectroscopy studies we draw the following conclusions:

- addition of ET to catalytic mixtures and heating of $(\mathrm{CON}+\mathrm{NC}+\mathrm{GL})$ contributes to the destruction of the hydrogen bonds present in $\mathrm{CON}+\mathrm{NC}$ and $\mathrm{CN}+\mathrm{NC}+\mathrm{HC}$;

- addition of ET promotes the formation of more polar molecules - micelles;

- interaction on complex formation took place with the participation of $\mathrm{C}-\mathrm{ON}$ groups of additives and reaction products.

\subsection{Structure of Binary Catalytic Systems}

The results of spectral studies of binary catalytic systems based on NC using additives of different nature (alcohols and nitrogen-containing modifiers) allow us to propose the following structural formulas of catalytic complexes (Fig. 6).

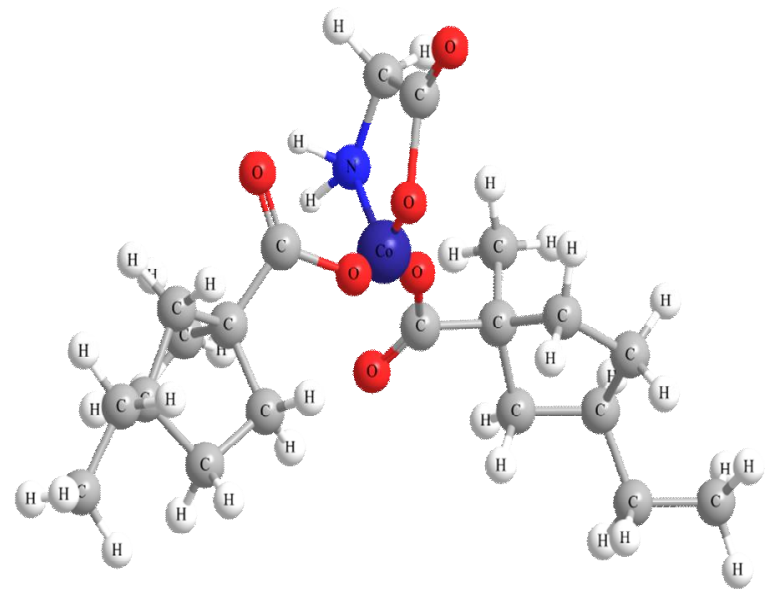

Fig. 6. The alleged catalytic complex of cobalt naphthenate with glycine

\section{Conclusions}

Conducted experiments and collected data show that use of catalytic systems that contain individual amino acids and industrial catalyst - solution of cobalt naphtenate with cyclohexanone - have certain influence on the process of liquid-phase homogeneous oxidation of cyclohexane.

First of all, use of amino acids does not lead to significant decrease of conversion of raw material (3.2$5.2 \%$ in comparison with $4.5-4.7 \%$ for industrial catalyst) allowing to use researched catalytic systems in industrial process of $\mathrm{CH}$ oxidation.

Secondly - [amino acid-industrial catalyst] catalytic systems showed properties of highly selective catalysts. Presence of amino acids leads to the increase in selectivity for aim products (up to $14 \%$ ) and the decrease in formation of by-products (ethers and dicarbonic acids). Such behavior, in addition to industrial-like conversion of cyclohexane, allows to increase a productivity of reaction equipment.

Thirdly - presence of amino acids allows not only to increase selectivity for aim products but also shifts the 
ratio of aim products $\mathrm{COL} / \mathrm{CON}$ towards creation of cyclohexanone. This allows to recommend the use of [amino acid-cobalt naphtenate] catalytic system in the process of Capron production.

Finally - the use of researched catalytic systems influences probably the most problematic stage of industrial cyclohexane oxidation - cleaning and recycling of reaction mixture. The decrease in formation of ethers and acids leads to significant decrease of amounts of additional reagents needed for cleaning of unreacted cyclohexane, and as final result - the decrease of sewage waters after the recycling process.

Conducted research showed great potential in use of amino acids as additives to industrial oxidation catalysts. As it was expected, amino acids significantly improve selectivity of catalytic systems. Large variety of amino acids and even larger possibility of their combinations might lead to creation of next level catalytical systems in terms of selectivity, productivity and lowering of reaction conditions.

\section{References}

[1] Ivashchuk O.: Visnyk Nats. Univ. Lvivska Polytechnika, 2012, 726, 172.

[2] Ivashchuk O., Reutskyy V., Mudryy S. et al.: Chem. Chem. Technol., 2012, 6, 339. https://doi.org/10.23939/chcht06.03.339

[3] Reutskyy V., Ivashchuk O., Mudryj S., Suprun O.: Abstracts of Actual Problems of Chemistry and Technology of Organic

Substances, Lviv 2012, 24.

[4] Riley C.: Open Catal. J., 2012, 5, 8. https://doi.org/10.2174/1876214X01205010008

[5] Ozeryanskii V., Gorbacheva A., Pozharskii A., Vlasenko M.:

Org. Biomol. Chem., 2015, 13, 8524.

https://doi.org/10.1039/C5OB01065A
[6] Suprun O., Reutskyy V., Ivashchuk O., Mudryj S.: Visnyk Nats. Univ. Lvivska Polytechnika, 2014, 787, 187.

[7] Arshadi M., Ghiaci M. et al.: J. Mol. Catal. A-Chem., 2011, 338, 71

[8] Melnyk Y., Reutskyy V., Melnyk S. et al.: Chem. Eng. Transact., 2011, 24, 163. https://doi.org/10.3303/CET1124028 [9] Malhotra S., Jaspal D., Malvia A.: Arab. J. Chem., 2019, 12, 1247. https://doi.org/10.1016/j.arabjc.2014.10.048

[10] Xie H., Hayes T., Gathergood N.: Catalysis of Reactions by Amino Acids [in:] Hughes A. (Ed.), Amino Acids, Peptides and Proteins in Organic Chemistry: Modified Amino Acids, Organocatalysis and Enzymes, V 2. Wiley-VCH Verlag GmbH 2010. https://doi.org/10.1002/9783527631780.ch7

[11] Yan N., Y. Wang: Chem, 2019, 2, 739

https://doi.org/10.1016/j.chempr.2019.03.016

[9] Kazicyna L., Kupletskaya N.: Ispolzovanie UF-, IK-I JaMRspectroskopii v organicheskoj himii, Vyshaya shkola, Moskva 1971. [10] Mironov V., Yankovkiy S.: Spectrografia v Organicheskoi Khimii. Khimia, Moskva 1985.

Received: April 02, 2020 / Revised: April 30, 2020 / Accepted: June 12, 2020

\section{ВПЛИВ АМІНОКИСЛОТ І СПИРТІВ НА КАТАЛІТИЧНЕ ОКИСНЕННЯ ЦИКЛОГЕКСАНУ}

Анотація. Показано, щзо використання каталітичних систем, щуо містять окремі амінокислоти та промисловий каталізатор - розчин нафтената кобальту в ииклогексанонімають певний вплив на процес рідиннофазного окиснення ииклогексану. В результаті проведення спектральних досліджень бінарних каталітичних систем на основі нафтената кобальту з використанням додатків різної природи (спиртів та азотовмісних модифікаторів) запропоновано структурні форми каталітичних комплексів.

Ключові слова: окиснення, каталізатор, ииклогексан, амінокислота. 